\title{
An Assessment of Seasonal Variation of Air Pollution in Benin City, Southern Nigeria
}

\author{
Verere Sido Balogun ${ }^{1 *}$, Oluwagbenga Oluwapamilerin Isaac Orimoogunje ${ }^{2}$ \\ ${ }^{1}$ Department of Geography and Regional Planning, University of Benin, Benin City, Nigeria \\ ${ }^{2}$ Department of Geography, Obafemi Awolowo University, Ile-Ife, Nigeria \\ Email: verere.sido@uniben.edu, ooorimoogunje@ouaife.edu.ng
}

Received 19 April 2015; accepted 2 June 2015; published 5 June 2015

Copyright (C) 2015 by authors and Scientific Research Publishing Inc.

This work is licensed under the Creative Commons Attribution International License (CC BY). http://creativecommons.org/licenses/by/4.0/

(c) (i) Open Access

\section{Abstract}

This study determined the effects of seasonality on air pollution in a tropical city of Southern Nigeria. This was with a view to acquiring data that would be useful in policy formulation and planning for proper management of ailments that result from seasonal variation of air pollution in the study area. Sampling for the study covered a period of six months, between mid-October 2013 and mid-April 2014. Air pollutants, taken into consideration, include particulate matter $\left(\mathbf{P M}_{0.3,0.5,1.0,2.5}\right.$, 5.0 and $10 \mu \mathrm{m}$ ) and carbon monoxide (CO). Particulate matter was measured using a hand-held particle counter, while CO was measured with a single gas monitor (T40 Rattler). Five sampling points were selected based on stratified sampling technique, which represented five land use types monitored in the study area. Sampling was carried out twice in a week in accordance with the guidelines of Central Pollution Control Board, Delhi India. Sampling height was two meters above ground level. The student $\mathrm{T}$-test was used to determine significant differences in monthly mean concentration of air pollutants across dry and wet seasons. The results revealed the dry season with mean values of $248568.19,64639.04,11140.21,2810.39,665.84,320.80$ particle counts for $\mathbf{P M}_{0.3,0.5,1.0,2.5,5.0}$ and 10um and $3.01 \mathrm{ppm}$ for $\mathrm{CO}$ concentration, was characterized by higher concentration of pollutants, while the rainy season with a mean values of 94728.24, 24745.69, 4338.29,

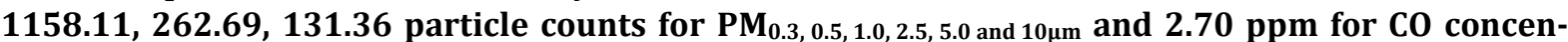
tration was characterized with less concentration of pollutants. The study concludes that seasonality significantly influences the concentration of pollutants in the city.

\section{Keywords}

Seasonality, Air Pollutants, Concentration, Variation

\footnotetext{
${ }^{*}$ Corresponding author.
} 


\section{Introduction}

Seasonality has always been a factor determining concentration of pollution in the lower atmosphere. Therefore introduction of contaminants such as $\mathrm{SO}_{2}, \mathrm{CO}, \mathrm{NO}_{2}$, particulates and Chlorofluorocarbons (CFCs) at toxic levels by natural processes and human activities could practically affect the quality of air, and in turn, the quality of life of living things [1]. Protecting citizens of a community, especially children from the health effects of air pollution is one of the most fundamental goals of environmental health researches and programs. There is therefore need to emphasize the connection between air quality and seasonality, so as to monitor trends in pollution and plan ahead for health challenges, which are linked to seasonal fluctuations in pollutant concentration. Ailments such as asthma, impairments in respiratory system, cough, nose and eye irritation have been linked to high concentration of repairable particulate matter [2], while deaths by suffocation and CO poisoning have also been reported by the Nigerian media severally. Ukpebor et al. reported that the months of May and June, 2008 recorded about 22 deaths from CO poisoning [3]. There are two major seasons in Nigeria: the dry and rainy seasons. The present study therefore provides baseline levels of particulate matter and carbon II oxide pollutants in the atmosphere of a typical tropical southern city and evaluates the diurnal trend of these pollutants, in order to acquire data for comparison with regulatory standards, and generate data that would be useful in policy formulation and planning for the proper management of ailments which are seasonally influenced by air pollutants.

\section{Study Area}

The study area is the typical tropical city of Benin located in the Southern geopolitical region of Nigeria as shown in Figure 1. It is bounded by latitude $6^{\circ} 30^{\prime} \mathrm{N}, 6^{\circ} 06^{\prime} \mathrm{N}$ and longitudes $5^{\circ} 30^{\prime} \mathrm{E}$ and $5^{\circ} 45^{\prime} \mathrm{E}$ (Western and Eastern boundaries) and has an estimated land area of 500 square kilometres [4]. The city falls within the tropical equatorial zone characterized by dry and wet seasons, with a estimated annual rainfall of over $2000 \mathrm{~mm}$ and average temperature of $27^{\circ} \mathrm{C}$ [5]. Wet season spans between the months of March and October, while the shorter dry season begins November and ends February. Averagely, rain falls all year round with double peak periods in the months of July and September, with a short temporal break in August. Benin City has a population of 3,218,332 [6] and comprises four local government areas, which include Ikpoba Okha, Oredo, Ovia North East and Egor local government areas.

\section{Method of Data Collection and Analysis}

The primary data includes air quality parameters collected from distributed sampling stations across the study area, coordinate values of which were captured with the use of GPS (Global Positioning System) device, marking sampling stations. Secondary data were sourced from previous literature related to the theme of the study. Stratified random sampling technique was used in selecting sites for administering air quality tests, for effective representation. Stratification of the study area was done based on the Australian Standard AS2922 [7]. Based on the AS2922 classification schemes, the siting of sampling units for the study satisfied the category "Neighbourhood Stations". Each neighbourhood station represented a land use class for which a sampling point was randomly selected. Table 1 shows the inventory of five sampling points chosen for the study as well as the land use activity each represents. Sampling frequency for both Particulate Matter and Carbon II Oxide was carried out twice weekly for six (6) months, beginning from mid-October 2013 to mid-April 2014, producing a total of 52 sample counts per sampling point. The two major pollutants considered include Particulate Matter $\left(\mathrm{PM}_{0.3}, \mathrm{PM}_{0.5}\right.$, $\mathrm{PM}_{1.0}, \mathrm{PM}_{2.5}, \mathrm{PM}_{5}$ and $\mathrm{PM}_{10 \mu \mathrm{m}}$ ) and Carbon II Oxide. The light scattering method was applied, by use of a CEM (Continuous Emission Monitoring) Particle Counter in detecting and counting air borne particles at a height of approximately two metres from ground level, while Carbon II Oxide concentrations were measured using a Single Gas Monitor called the T40 Rattler at same height. Readings for mean temperature and relative humidity were also derived from the field using an in-built temperature and humidity probe in the hand-held particle counter. The independent-samples $\mathrm{T}$ test was applied to determine significant differences in monthly variations of air parameter readings. The arithmetic mean was used in constricting a wide array of air quality data derived from the field.

\section{Results and Discussion}

The results obtained from the field assessment of air quality parameters ( $\mathrm{PM}_{0.3-10 \mu \mathrm{m}}$ and Carbon Monoxide) are 

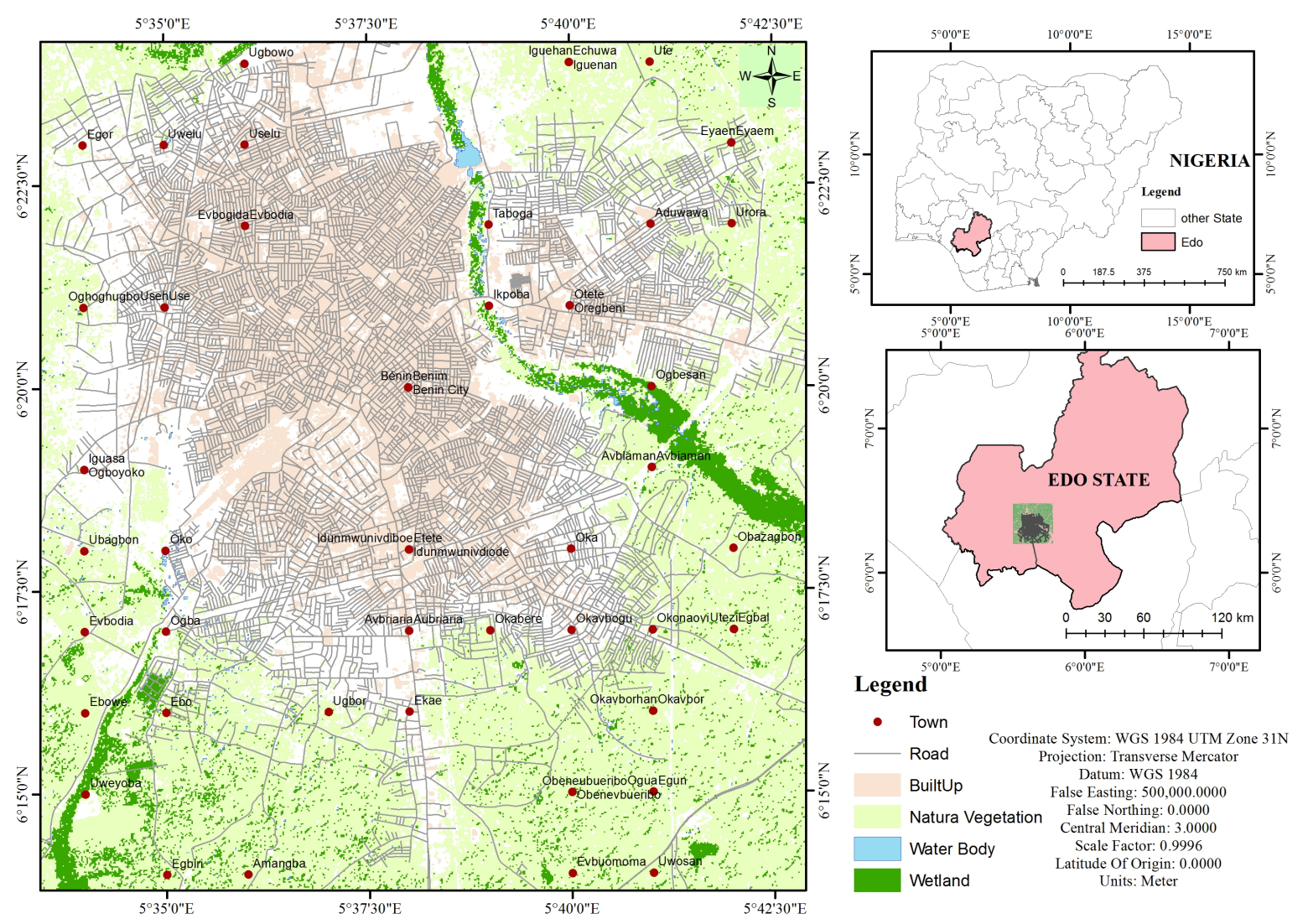

Figure 1. Benin City (Insert: Edo State, Insert: Nigeria).

Table 1. Names and location of sampling points.

\begin{tabular}{|c|c|c|c|}
\hline Locations & Land Use Type & Coordinates & Altitude (meters) \\
\hline University of Benin & Institutional & $\begin{array}{l}\text { Lat } 6^{\circ} 23^{\prime} 47.8^{\prime \prime} \mathrm{N} \\
\text { Long } 5^{\circ} 37^{\prime} 30.2^{\prime \prime E}\end{array}$ & 103 \\
\hline $\begin{array}{l}\text { PPRH Plantation } \\
\text { Ugbowo. }\end{array}$ & Agricultural & $\begin{array}{l}\text { Lat } 6^{\circ} 24^{\prime} 15.3^{\prime \prime} \mathrm{N} \\
\text { Long } 5^{\circ} 36^{\prime} 16.1^{\prime} \mathrm{E}\end{array}$ & 114 \\
\hline Ring Road & Commercial & $\begin{array}{l}\text { Lat } 6^{\circ} 19^{\prime} 53.1^{\prime} \mathrm{N} \\
\text { Long } 5^{\circ} 37^{\prime} 26.5^{\prime} \mathrm{E}\end{array}$ & 84 \\
\hline Ikpoba Hill/Agbor Road & Indutrial & $\begin{array}{l}\text { Lat } 6^{\circ} 20^{\prime} 52.4^{\prime \prime} \mathrm{N} \\
\text { Long } 5^{\circ} 40^{\prime} 6.6^{\prime} \mathrm{E}\end{array}$ & 115 \\
\hline Akugbe/Eweka Road & Residential & $\begin{array}{l}\text { Lat } 6^{\circ} 21 ' 36.6^{\prime} \mathrm{N} \\
\text { Long } 5^{\circ} 37^{\prime} 55.3^{\prime \prime E}\end{array}$ & 90 \\
\hline
\end{tabular}

presented in tables. The values in Tables 2-7 represent monthly mean values of particle counts $\left(\mathrm{PM}_{0.3,0.5,1.0,2.5 \text {, }}\right.$ 5.0 and $10 \mathrm{\mu m}$ ) for air pumped at the rate of $0.1 \mathrm{ft}^{3} /$ minute for an averaging period of 10 minutes. While the values in Table 8 represents monthly mean values of CO concentration in PPM, run for an averaging period of 15 minutes. Table 9 shows the results of the independent-samples $\mathrm{T}$ test, which determined if there were significant differences in seasonal mean values of all air quality parameters. The results reveal significant differences in seasonal variations for all categories of particulate matter where $\mathrm{P}=0.00<0.05$. Nevertheless, results for CO concentration reveal no significant difference with respect to seasonality where $\mathrm{P}=0.07>0.05$ ( $5 \%$ significance level). Therefore, we can conclude that seasonality affects the quality of air for all land use types in the study area, especially for particulate matter concentration.

Seasonal and Spatial variations have been represented using line graphs in Figures 2-8. It is evident from the graphs that peak mean values for $\mathrm{PM}_{(0.3,0.5}$ and 1.0)pm were recorded in the dry season month of November, that for 
Table 2. Monthy values of $\mathrm{PM}_{0.3 \mu \mathrm{m}}$.

\begin{tabular}{cccccccc}
\hline \multirow{2}{*}{ Land Use } & \multicolumn{7}{c}{ Average Monthly Particle Counts (2013/2014) } \\
\cline { 2 - 8 } & October & November & December & January & February & March & April \\
\hline Institutional & 69321 & 176903 & 254900 & 237635 & 268376 & 88142 & 58588 \\
Agricultural & 61110 & 196718 & 243610 & 245347 & 265185 & 86144 & 58711 \\
Commercial & 132772 & 367649 & 303180 & 363114 & 275478 & 109394 & 94128 \\
Industrial & 187991 & 476602 & 306854 & 298763 & 270036 & 95172 & 82945 \\
Residential & 163232 & 273716 & 280665 & 271515 & 262195 & 102016 & 66642 \\
\hline
\end{tabular}

Table 3. Monthly values of $\mathrm{PM}_{0.5 \mu m}$.

\begin{tabular}{cccccccc}
\hline \multirow{2}{*}{ Land Use } & \multicolumn{3}{c}{ Average Monthly Particle Counts (2013/2014) } \\
\cline { 2 - 8 } & October & November & December & January & February & March & April \\
\hline Institutional & 18699 & 38011 & 66951 & 56035 & 84932 & 23964 & 16666 \\
Agricultural & 14055 & 47926 & 65611 & 56369 & 83981 & 24132 & 17068 \\
Commercial & 36066 & 88617 & 78917 & 82198 & 83254 & 29817 & 26110 \\
Industrial & 44671 & 154306 & 79402 & 67065 & 81176 & 26725 & 23608 \\
Residential & 36739 & 60868 & 74243 & 61862 & 84394 & 28251 & 19076 \\
\hline
\end{tabular}

Table 4. Monthly values of $\mathrm{PM}_{1.0 \mu m}$.

\begin{tabular}{cccccccc}
\hline \multirow{2}{*}{ Land Use } & \multicolumn{7}{c}{ Average Monthly Particle Counts (2013/2014) } \\
\cline { 2 - 7 } & October & November & December & January & February & March & April \\
\hline Institutional & 2407 & 5371 & 12351 & 8949 & 17892 & 4548 & 3148 \\
Agricultural & 2260 & 7215 & 12426 & 9210 & 17965 & 4650 & 3242 \\
Commercial & 7162 & 13227 & 14651 & 12374 & 16829 & 5763 & 4590 \\
Industrial & 7720 & 19253 & 14283 & 10521 & 16511 & 5295 & 4374 \\
Residential & 5528 & 8569 & 13882 & 10195 & 17826 & 5278 & 3630 \\
\hline
\end{tabular}

Table 5. Monthly values of $\mathrm{PM}_{2.5 \mu m}$.

\begin{tabular}{cccccccc}
\hline \multirow{2}{*}{ Land Use } & \multicolumn{3}{c}{ Average Monthly Particle Counts (2013/2014) } \\
\cline { 2 - 8 } & October & November & December & January & February & March & April \\
\hline Institutional & 555 & 1162 & 3148 & 2089 & 5300 & 1148 & 771 \\
Agricultural & 492 & 1577 & 3286 & 2188 & 5380 & 1181 & 792 \\
Commercial & 2303 & 2878 & 4198 & 2709 & 4811 & 1500 & 1093 \\
Industrial & 2783 & 3108 & 3783 & 2447 & 4769 & 1375 & 1050 \\
Residential & 1136 & 1760 & 3731 & 2498 & 5578 & 1373 & 902 \\
\hline
\end{tabular}

Table 7. Monthly values of $\mathrm{PM}_{10.0 \mu m}$.

\begin{tabular}{|c|c|c|c|c|c|c|c|}
\hline \multirow{2}{*}{ Land Use } & \multicolumn{7}{|c|}{ Average Monthly Particle Counts (2013/2014) } \\
\hline & October & November & December & January & February & March & April \\
\hline Institutional & 61 & 128 & 325 & 216 & 629 & 109 & 82 \\
\hline Agricultural & 57 & 169 & 362 & 234 & 660 & 118 & 83 \\
\hline Commercial & 346 & 339 & 544 & 278 & 578 & 176 & 97 \\
\hline Industrial & 307 & 316 & 462 & 261 & 592 & 148 & 102 \\
\hline Residential & 131 & 184 & 481 & 292 & 611 & 156 & 96 \\
\hline
\end{tabular}


Table 8. Monthly values of CO concentration.

\begin{tabular}{cccccccc}
\hline & \multicolumn{7}{c}{ Average Monthly CO Concentration in PPM (2013/2014) } \\
\cline { 2 - 7 } Land Use & October & November & December & January & February & March & April \\
\hline Institutional & 2 & 0 & 3 & 3 & 3 & 2 & 2 \\
Agricultural & 1 & 0 & 2 & 3 & 2 & 2 & 2 \\
Commercial & 5 & 3 & 4 & 6 & 4 & 3 & 4 \\
Industrial & 5 & 2 & 4 & 4 & 3 & 3 & 3 \\
Residential & 0 & 1 & 3 & 4 & 4 & 3 \\
\hline
\end{tabular}

Table 9. The independent sample T-Test result for seasonal variation.

\begin{tabular}{ccc}
\hline Air Pollutant & F-value & Significance Value (P) \\
\hline $\mathrm{PM}_{0.3 \mu \mathrm{m}}$ & 17.616 & 0.000 \\
$\mathrm{PM}_{0.5 \mathrm{~mm}}$ & 13.088 & 0.000 \\
$\mathrm{PM}_{1.0 \mathrm{~mm}}$ & 16.440 & 0.000 \\
$\mathrm{PM}_{2.5 \mathrm{~mm}}$ & 11.546 & 0.001 \\
$\mathrm{PM}_{5.0 \mathrm{~mm}}$ & 9.060 & 0.003 \\
$\mathrm{PM}_{10 \mu \mathrm{m}}$ & 8.466 & 0.004 \\
$\mathrm{CO}(\mathrm{PPM})$ & 3.240 & 0.073 \\
\hline
\end{tabular}

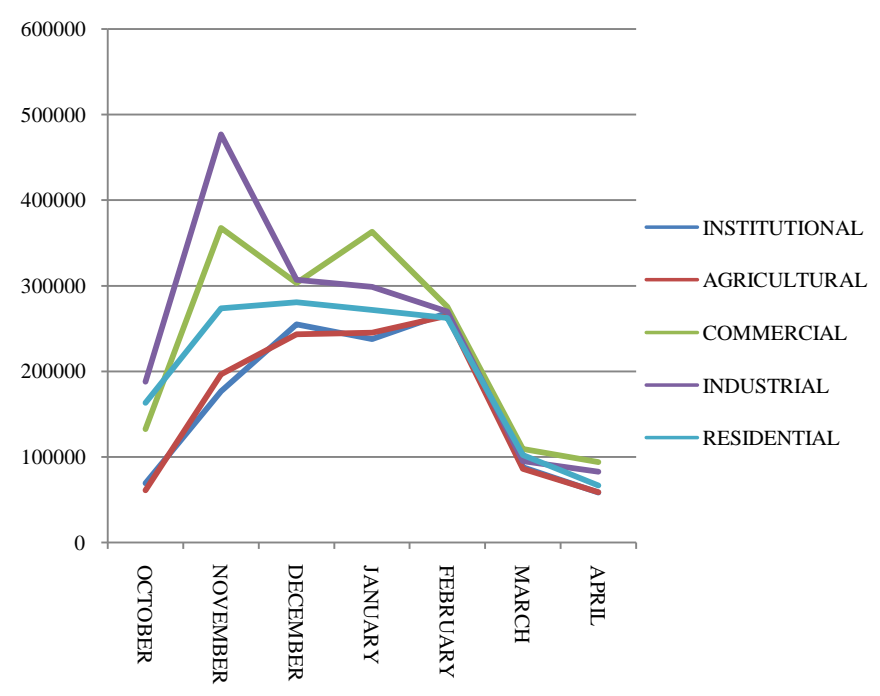

Figure 2. Mean particle counts for $\mathrm{PM}_{0.3 \mu \mathrm{m}}$.

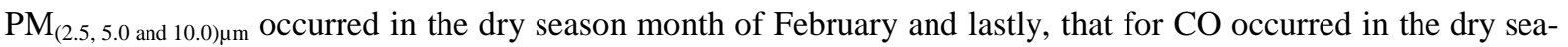
son month of January. Minimum mean values for particulate matter for all sizes sampled, occurred in the wet season month of April, while minimum mean value of CO was recorded in the dry season month of November.

Meteorological factors which influence the dispersion and dilution of pollutants include wind speed, atmospheric temperature and relative humidity. These explained seasonal differences in concentration of pollutants. This corroborates the postulation by Jacobson, that low wind speed, high temperature and low humidity reduce the rate of dispersion of air pollutants, thus increasing ground concentration of same pollutants and vice versa. Also, higher concentration of pollutants observed during the dry season could be a result of higher ambient 


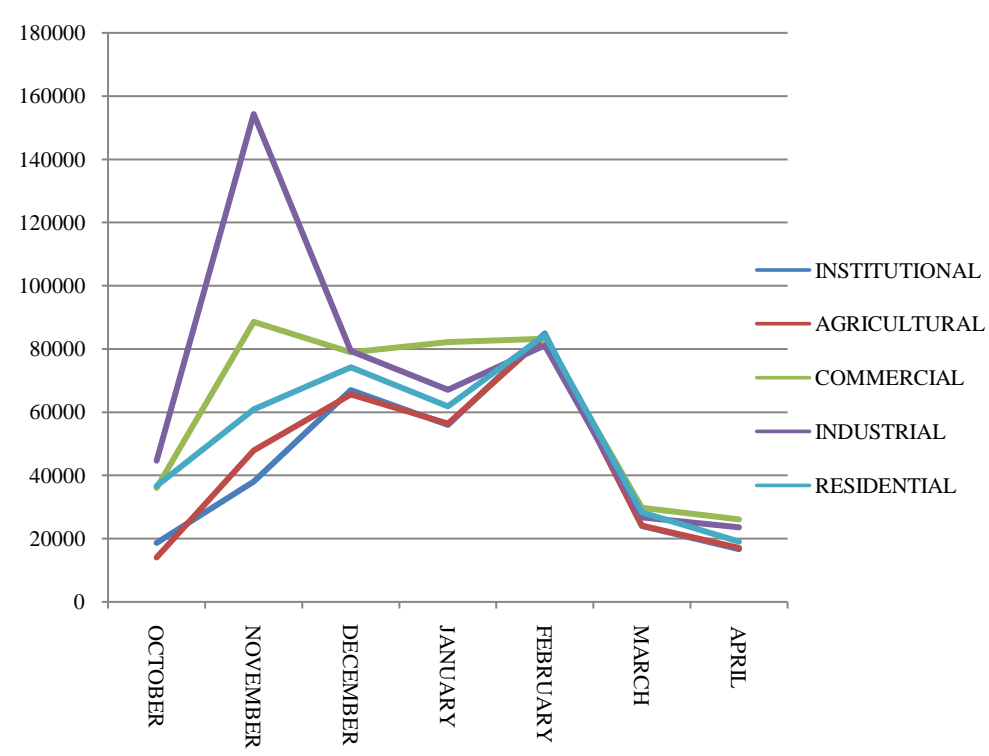

Figure 3. Mean particle counts for $\mathrm{PM}_{0.5 \mu \mathrm{m}}$.

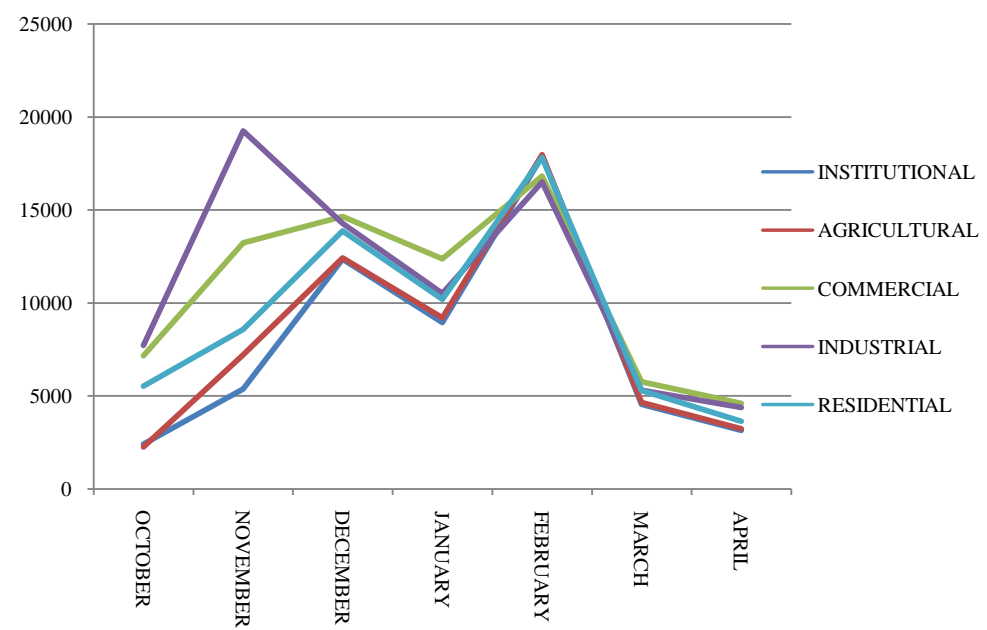

Figure 4. Mean particle counts for $\mathrm{PM}_{1.0 \mu \mathrm{m}}$.

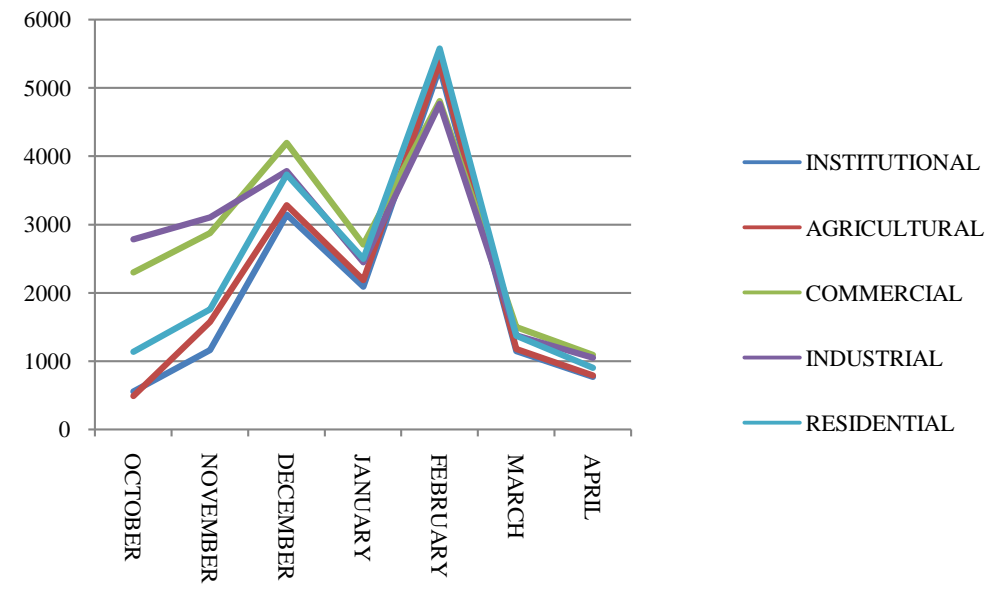

Figure 5. Mean particle counts for $\mathrm{PM}_{2.5 \mu \mathrm{m}}$. 


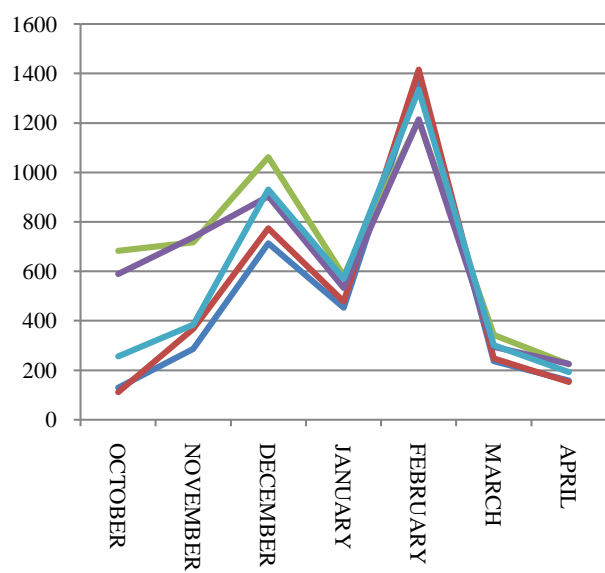

— INSTITUTIONAL

— AGRICULTURAL

COMMERCIAL

—INDUSTRIAL

$\longrightarrow$ RESIDENTIAL

Figure 6. Mean particle counts for $\mathrm{PM}_{5.0 \mu \mathrm{m}}$.

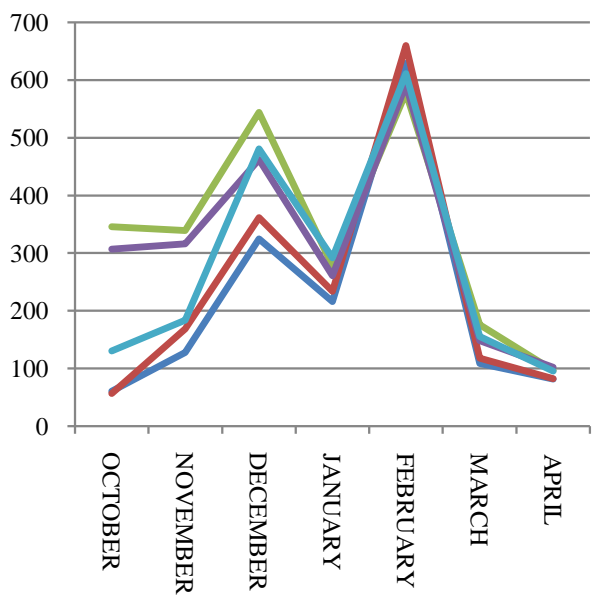

INSTITUTIONAL

— AGRICULTURAL

COMMERCIAL

IINDUSTRIAL

- RESIDENTIAL

Figure 7. Mean particle counts for $\mathrm{PM}_{10 \mu \mathrm{m}}$.

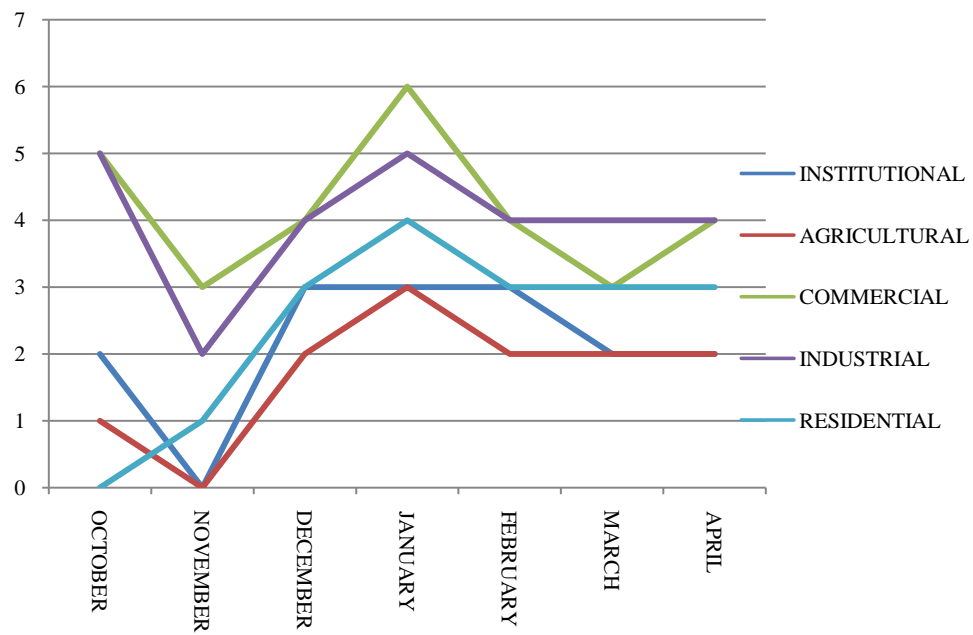

Figure 8. Mean co concentrations (PPM).

temperatures, leading to downward movement of pollutants and consequently high ground level concentrations. If temperature of pollutant gases is higher than the surrounding air, the plumes will tend to rise. On the other 
hand, if temperature of ambient air is higher, pollutant gases become concentrated at ground level [8]. Therefore atmospheric temperature is thus an important factor for the dispersion of pollutant gases, as the larger the difference between cool ambient air and plumes, the higher the plume rises, so also the rate of dispersion or spread of pollutants from its source before it reaches ground level. Relative humidity is also another meteorological factor that explains the concentration of pollutants at a point. Rene revealed that relative humidity is generally higher during the wet season. High relative humidity results to lower atmospheric temperature, and consequently high rate of plume ascent, and vice versa [9]. In Nigeria, dry seasons are characterized by high temperatures and low humidity, while the reverse is the case for wet seasons. This explains why higher readings were recorded for almost all pollutants during the dry season months, when compared with lower readings recorded during the rainy season months. Wind speed is generally low in Benin City, when compared with some other regions of the world. For instance, a study on variations in CO levels in Benin City recorded a wind speed range of 0.0 - 1.5 $\mathrm{ms}^{-1}$ at all sampling sites [10]. Low wind speed reduces the ability of the atmosphere to disperse high dose of emitted $\mathrm{CO}$ and particulate matter.

Table 10 describes 9 classes of environments ranging from class 1 (representing the cleaner class) to class 9 , (representing the dirtier class). Note that $1 \mathrm{~meter}^{3}$ of sampled air $=35.315 \mathrm{ft}^{3}$ of sampled air

Therefore deriving mean values of particle counts for $35.315 \mathrm{ft}^{3}$ of air from $0.1 \mathrm{ft}^{3}$ of sampled air is calculated as;

$$
\text { Particle count per } 35.315 \mathrm{ft}^{3} \text { of pumped air }=\frac{\text { particle count per } 0.1 \mathrm{ft}^{3} \text { of air pumped } \times 35.315}{0.1}
$$

By comparing them with mean values derived from the field in Table 11 and Table 12, we notice that all land use types in the study area fall into the categories of the classes 6, 8 and 9, which represent "moderately dirty", "dirty" and "very dirty" environments. For Carbon Monoxide, the regulatory limit of 90 ppm for 15 minutes was not exceeded. Nevertheless it is needful to understand that current air quality standards are to a large extent based on the concept of an 'effect threshold', below which significant health effects are not likely to occur. However, no such threshold is exclusively guaranteed. Therefore, even if the limit is not exceeded, significant health impacts may result. In other words, reductions in pollutant concentration below current standards are expected to result in health benefits, but do not guarantee a zero adverse health effect. Moreover, air quality guidelines designed to protect the general population in the area may be insufficient to protect babies, children, elderly, fragile and other susceptible group of individuals.

\section{Implication of the Study}

Results from this study have shown that concentrations of pollutants are generally higher in the dry season,

Table 10. Classess of 'cleaner' and 'dirtier' environments based on particle count concentration.

\begin{tabular}{|c|c|c|c|c|}
\hline \multirow{2}{*}{$\begin{array}{l}\text { Critical Environ- } \\
\text { ment Classification } \\
\text { (ISO 14644-1) }\end{array}$} & \multicolumn{4}{|c|}{ Concentration $\left(\right.$ particles $/$ meter $\left.^{3}\right)>$ or $=$ Size Shown } \\
\hline & $\{$ Sum $\} \mathrm{PM}_{(0.1,0.2 \& 0.3) \mu \mathrm{m}}$ & $\mathrm{PM}_{0.5 \mu \mathrm{m}}$ & $\mathrm{PM}_{1.0 \mu \mathrm{m}}$ & $\mathrm{PM}_{5.0 \mu \mathrm{m}}$ \\
\hline 1 & 12 & & & \\
\hline 2 & 134 & 4 & & \\
\hline 3 & 1,339 & 35 & 8 & \\
\hline 4 & 13,390 & 352 & 8 & \\
\hline 5 & 133,900 & 3,520 & 832 & 29 \\
\hline 6 & $1,339,000$ & 35,200 & 8,320 & 293 \\
\hline 7 & & 352,000 & 83,200 & 2,930 \\
\hline 8 & & $3,520,000$ & 832,000 & 29,300 \\
\hline 9 & & $35,200,000$ & $8,320,000$ & 293,000 \\
\hline
\end{tabular}

Source [11]. 
Table 11. Particle counts per $35.315 \mathrm{ft} 3$ of air volume sampled in the rainy season.

\begin{tabular}{ccccccc}
\hline Sampling & \multicolumn{5}{c}{ Mean Values of Particle Counts per 35.315ft3 of Pumped Air } \\
\cline { 2 - 7 } Location & $\mathrm{PM}_{0.3 \mu \mathrm{m}}$ & $\mathrm{PM}_{0.5 \mu \mathrm{m}}$ & $\mathrm{PM}_{1.0 \mathrm{~mm}}$ & $\mathrm{PM}_{2.5 \mu \mathrm{m}}$ & $\mathrm{PM}_{5.0 \mu \mathrm{m}}$ & $\mathrm{PM}_{10 \mu \mathrm{m}}$ \\
\hline Uniben (Institutional) & $26,493,313$ & $7,267,121$ & $1,282,641$ & 316,776 & 66,392 & 31,784 \\
Environmental Class & 8 & 6 & 6 & - & 9 & - \\
PPRH (Agricultural) & $25,492,133$ & $6,951,051$ & 1,297120 & 319,248 & 66,039 & 32,843 \\
Environmental Class & 8 & 6 & 6 & - & 9 & - \\
Ring Road (Commercial) & $38,989,173$ & $10,664,071$ & $2,029,553$ & 554,092 & 137,022 & 68,158 \\
Environmental Class & 8 & 6 & 6 & - & 9 & - \\
Ikpoba/Agbor Road(Industrial) & $40,052,860$ & $10,605,448$ & $1,975,894$ & 568,572 & 121,130 & 60,742 \\
Environmental Class & 8 & 6 & 6 & - & 9 & - \\
Akugbe/ Eweka (Residential) & $37,439,197$ & $9,728,929$ & $1,713,484$ & 416,364 & 91,113 & 46,616 \\
Environmental Class & 8 & 6 & 6 & - & 9 & - \\
\hline
\end{tabular}

Source: Field Work, Benin City 2013/2014.

Table 12. Particle counts Per $35.315 \mathrm{ft} 3$ of air volume sampled in the dry season.

\begin{tabular}{|c|c|c|c|c|c|c|}
\hline \multirow{2}{*}{$\begin{array}{l}\text { Sampling } \\
\text { Location }\end{array}$} & \multicolumn{6}{|c|}{ Mean Values of Particle Counts per $35.315 \mathrm{ft} 3$ of Pumped Air } \\
\hline & $\mathrm{PM}_{0.3 \mu \mathrm{m}}$ & $\mathrm{PM}_{0.5 \mu \mathrm{m}}$ & $\mathrm{PM}_{1.0 \mu \mathrm{m}}$ & $\mathrm{PM}_{2.5 \mu \mathrm{m}}$ & $\mathrm{PM}_{5.0 \mu \mathrm{m}}$ & $\mathrm{PM}_{10 \mu \mathrm{m}}$ \\
\hline Uniben (Institutional) & $84,061,354$ & $21,184,762$ & $3,756,103$ & 964,200 & 228,488 & 105,239 \\
\hline Environmental Class & 8 & 6 & 6 & - & 9 & - \\
\hline PPRH (Agricultural) & $83,744,578$ & $21,829,261$ & $3,946,098$ & $1,027,313$ & 246,499 & 115,833 \\
\hline Environmental Class & 8 & 6 & 6 & - & 9 & - \\
\hline Ring Road (Commercial) & $117,246,860$ & $29,278,607$ & $4,938,096$ & $1,247,679$ & 302,650 & 147,970 \\
\hline Environmental Class & 8 & 6 & 6 & - & 9 & - \\
\hline Ikpoba/Agbor Road (Industrial) & $118,940,567$ & 32,824,939 & 5,162347 & $1,192,941$ & 283,226 & 136,669 \\
\hline Environmental Class & 8 & 6 & 6 & - & 9 & - \\
\hline Akugbe/Eweka (Residential) & $96,422,310$ & $24,379,710$ & $4,303,132$ & $1,133,612$ & 268,747 & 132,784 \\
\hline Environmental Class & 8 & 6 & 6 & - & 9 & - \\
\hline
\end{tabular}

Source: Field Work, Benin City 2013/2014.

while low wind speed in the city has been observed to be responsible for poor dilution and dispersion of contaminants. This validates previous study [3]. Higher concentration of pollutants during dry seasons implies that certain social and policy changes should be put in place to curb associated health risks involved. Automobile exhaust, open solid waste burning, industrial emission and fugitive dusts from non-tar road surfaces have been identified as the main sources of air pollutants in Benin City [10]. Therefore stake holders should initiate policies and efforts geared towards reducing traffic especially during rush hours, tarring of dusty roads, ensuring proper disposal of solid waste remotely and implementing a dependable mass transit system to reduce the number of vehicles plying the city roads. Benin City has quite a number of interconnecting routes and small streets requiring rehabilitation. Proper rehabilitation of theses road would reduce concentration of fugitive dust emanating from the disturbance of non-tar surfaces.

\section{Conclusion}

Results from the study have shown that seasonality significantly varies with air pollutant concentration. The independent sample T-test revealed significant difference of 0.00 in mean variation for concentration of particulate 
matter between the dry and rainy seasons. In comparison to standards, values for $\mathrm{PM}_{0.3-10.0 \mu m}$ have categorised the environments of all the land use classes in the study area as the "moderately dirty" class 6 and "dirtier" classes 8 and 9. Values for CO did not exceed 90 ppm, which is the WHO limit for 15 minutes. Except for CO, mean values of particulate matter of all sizes were generally higher in the dry season compared with the rainy season. This study therefore concludes that seasonality influences the concentration of pollutants in the city. Policies and actions by stake holders should be geared towards use of cleaner energy, proper waste management and rehabilitation of dirt roads.

\section{References}

[1] WHO Regional Office for Europe (2000) Air Quality Guidelines. 2nd Edition, Copenhagen.

[2] Ndiokwere, C.L. (2004) Chemistry and the Environment. A Synopsis, University of Benin, Benin City. http://www.nuc.edu.ng/nucsite/File/ILS\%202004/ILS-133.pdf

[3] Ukpebor, E.E., Ukpebor, J.E., Eromomene, F., Odiase, J.I. and Okoro, D. (2010) Spatial and Diurnal Variations of Carbon Monoxide (CO) Pollution from Motor Vehicles in an Urban Space. Polish Journal of Environmental Studies, 19, 817-823.

[4] Erah, P.O., Akujieze, C.N. and Oteze, G.E. (2002) The Quality of Ground Water in Benin City: A Baseline Study on Inorganic Chemicals and Microbial Contaminants of health Importance in Boreholes and Open Wells. Tropical Journal of Pharmaceutical Research, 1, 75-82.

[5] Omofonmwan, S.I. and Eseigbe, J.O. (2009) Effects of Solid Waste on the Quality of Underground Water in Benin Metropolis, Nigeria. Journal of Human Ecology, 26, 99-105.

[6] National Bureau of Statistics (2009) Social Statistics in Nigeria. Official Results of the 2006 National Census. www.nigerianstat.gov.ng

[7] Australian Standard 2922 (1987) Ambient Air—Guide for the Siting of Sampling Units. Standards Association of Australia, Home bush NSW, Australia.

[8] Jacobson, M.Z. (2005) Fundamentals of Atmospheric Modelling. 2nd Edition, Cambridge University Press, New York. http://dx.doi.org/10.1017/CBO9781139165389

[9] Rene, G.T. (2008) An Air Quality Baseline Assessment for the Vaal Air Shed in South Africa. A Master Thesis Dissertation, Geoinformatics and Meteorology Department, University of Pretoria, South Africa.

[10] Ukpebor, E.E., Ukpebor, J.E., Oviasogie, P.O., Odiase, J.I. and Egbeme, M.A. (2006) Field Comparison of Total Suspended Particulates (TSP) Samplers to Assess Spatial Variation. International Journal of Environmental Studies, 63, 567-577. http://dx.doi.org/10.1080/00207230600963866

[11] International Standards Organisation ISO 14644-1 (1999) Clean Rooms and Associated Controlled Environments-Part 1: Classification of Air Cleanliness. www.iso.org/iso/catalogue 